\title{
POLICE AND JUDICIAL COOPERATION BETWEEN THE EUROPEAN UNION MEMBER STATES. RESULTS AND PROSPECTS
}

\author{
Sabine Gless
}

\section{Introduction}

'Anything goes. Nothing works.' This statement is true in quite a number of cases. Can it also be applied when it comes to the mechanisms and principles of police and judicial cooperation within the EU?

Official EU documents, including the papers from the High-Level Advisory Group on the Future of European Home Affairs Policy, perhaps admit the first part of the phrase, but would certainly refute the second. ${ }^{1}$ However, the 'medley of collaborations' and difficulties in implementing the numerous instruments have been the subject of criticism for some time. ${ }^{2}$ In order to find an answer to this question one should consider the following points.

First, one has to examine whether it is true that 'anything goes' in police cooperation and judicial cooperation 'between the EU Member States'. In doing so, one has to look at the results, or rather facts of police and judicial cooperation in the EU today.

1 High-Level Advisory Group on the Future of European Home Affairs Policy, Proposed Solutions for the Future EU Justice Programme of June 2008 (Brussels 2008).

2 See M. Anderson and J. Apap (eds), Striking a Balance between Freedom, Security and Justice in an Enlarged European Union (Brussels 2002), p. 1; see e.g. C. Fijnaut, 'Transnational Organized Crime and Institutional Reform in the European Union', in P. Williams and D. Vlassis (eds), Combating Transnational Crime. Concepts, Activities and Responses (London 2001), pp. 287-289; S. Gless, 'Introduction vor Hauptteil III', in W. Schomburg, O. Lagodny, S. Gless and T. Hackner, Internationale Rechtshilfe in Strafsachen, 4thedn (Munich 2006), no. 97; M. Daman, 'Cross-Border HotPursuit in the EU', European Journal of Crime, Criminal Law and Criminal Justice (2008), pp. 204-206. 
Secondly, one has to assess whether it is true that nothing works. In doing so, the problems of police and judicial cooperation from a lawyer's point of view will be the main focus.

Following this analysis, possible solutions to these problems will be presented, which also outline the prospects for police and judicial cooperation in the future. Special emphasis will be placed on the options of the Lisbon Treaty and the question of whether the treaty may help make cooperation work better. This discussion also includes a closer look at the working mechanism of such cooperation.

Finally some principles, effectively or with the intention of governing police and judicial cooperation between EU Member States, are put up for discussion, including also the question - resulting from the Pupino judgement - of whether the recently established duty of loyal cooperation may eventually herald a new era of sharing and shaping responsibilities in the fight against cross-border crime in the European Union; also in the light of a solidarity, which might even eventually enable the Union to build sovereignty in cross-border law enforcement.

\section{Definitions}

The question whether anything goes with regard to police and judicial cooperation between EU Member States leads to the question: what is police and judicial cooperation all about in the first place? Lawyers from civil law jurisdictions usually start with definitions to answer to such questions:

\subsection{Police and Judicial Cooperation}

Interestingly enough, the treaties of the European Union do not define police and/or judicial cooperation as such. The Lisbon Treaty, in its Art. 87, outlines a description of police collaboration only very roughly:

'The Union shall establish police cooperation involving all the Member States' competent authorities, including police, customs and other specialised law enforcement services in relation to the prevention, detection and investigation of criminal offences.'

Furthermore, it provides for European legislation with regard to cross-border law enforcement in Art. 89:

'The Council, acting in accordance with a special legislative procedure, shall lay down the conditions and limitations under which the competent authorities of the Member States referred to in Articles 82 and 87 may operate in the territory of another Member State in liaison and in agreement with the authorities of that State. The Council shall act unanimously after consulting the European Parliament.' 
While outlining Europol's mission in Art. 88, with regard to judicial cooperation, the Lisbon Treaty merely states in Art. 82:

'Judicial cooperation in criminal matters in the Union shall be based on the principle of mutual recognition of judgements and judicial decisions ... and shall include the approximation of the laws and regulations of the Member States in the areas referred to in paragraph 2 and in Article 83.'

But to evaluate the results of police and judicial cooperation, as we want to do here, we need to clarify these terms first. Searching for a definition, for example in official documents, research papers or academic publications, or even in Wikipedia, one realises that different criteria and approaches are necessary in order to sum up today's police and judicial cooperation in the EU. ${ }^{3}$ Basically, three criteria are necessary, they illustrate what is going on and thus present the 'results' of this kind of cooperation:

1) the inter-State element;

2) the degree of the organisation of a (formal) framework or even institution building; and

3) the dependence upon European law (in a broad sense).

\subsection{Cooperation 'Between the Member States' and Cooperation in the European Union}

Examining judicial and police cooperation in the EU framework - even at first sight - one finds many different layers that need to be sorted. ${ }^{4}$ There is - traditionally, and predating the EU itself - cooperation between the EU Member States. ${ }^{5}$ Today, however, there is further specific cooperation within the European Union as well as special cooperation between EU Member States and formally associated States (i.e., in an institutionalised framework).

3 M. den Boer, 'Towards an Accountability Regime for an Emerging European Policing Governance', Policing and Society (2002), pp. 275-289; D. Flore, 'Les acteurs d'un système de justice pénale européen', in G. de Kerchove and A. Weyembergh (eds), Vers un espace judiciaire pénal européen (Brussels 2000), p. 81; W. Bruggeman, 'Europol et Interpol', in G. de Kerchove and A. Weyembergh (eds), op. cit., p. 97; S. Brammertz, 'Eurojust. Parquet européen de la première génération', in G. de Kerchove and A. Weyembergh (eds), op. cit., p. 105.

4 Not to mention the different police forces and varying competences in the Member States, see M. Anderson and J. Apap (eds), op. cit., p. 47.

5 See H. Satzger and F. Zimmermann, 'From Traditional Models of Judicial Assistance to the Principle of Mutual Recognition. New Developments of the Actual Paradigm of the European Cooperation in Penal Matters', in M. Bassiouni, V. Militello and H. Satzger (eds), European Cooperation in Penal Matters. Issues and Perspectives (Padova 2008), p. 339. 
Mutual legal assistance in criminal matters between the EU Member States takes place on the basis of the Mutual Assistance Convention of 2000 and its protocols. ${ }^{6}$ Furthermore, the competent authorities cooperate through European agencies like Europol or Eurojust. While the 2000 Convention merely facilitates existing cooperation on the basis of the 1959 Council of Europe Convention on Mutual Assistance in Criminal Matters and its 1978 Protocol, Europol and Eurojust add a new dimension: being central institutions, staffed with liaison agents from all Member States, they facilitate cooperation not only by means of data exchange, but through communication and problem shooting on an ad hoc basis.

A prominent example of collaboration within the EU is the teamwork of national and European agents fighting fraud that affects EC financial interests. The work of the European Anti-Fraud Office, the so-called OLAF, adds a new characteristic feature to this cooperation. ${ }^{7}$

The Schengen Agreement ${ }^{8}$ provides an example of institutionalised collaboration between EU Member States and non-Member States, namely Iceland, Norway $^{9}$ and Switzerland ${ }^{10}$ (as well as Liechtenstein in the near future).

Other forms of cooperation could be added, especially EU missions that take place in the framework of the Second Pillar, although the objective is one of law enforcement.

\section{Facts}

It is common knowledge that a gap exists between the theoretical and the practical approach towards police and judicial cooperation. My task during this conference is to present the theory - on paper. The approaches of practitioners will be part of workshops. However, the many points of intersection between theory and practice are important and should be included in further research. For example,

6 EU Convention on Mutual Assistance in Criminal Matters between the Member States of the EU of 29.5.2000, Official Journal, C 197, 12.7.2000, p. 1 (EU Convention on MACM of 2000) and its Protocol of 16.10.2001, Official Journal, C 326, 21.11.2001, p. 1.

7 For further information see R. Traşcã, 'La place de l'Office Européen de Lutte Antifraude dans la répression de la fraude au budget communautaire', Cahiers de droit européen (2008), p. 7.

8 Founded on Convention Implementing the Schengen Agreement of 14 June 1985 between the governments of the Benelux Economic Union, the federal Republic of Germany and the French Republic on the gradual abolition of checks at their common borders of 19 June 1990 (Schengen Implementing Convention of 1990); for further information on the growing Schengen acquis see e.g.: Official Journal, L 370, 17.12.2004, p. 78.

9 See Official Journal, L 176, 10.7.1999, p. 36.

10 See Official Journal, L 327, 5.12.2008, p. 15 with further references. 
experience of the last decade in different areas has shown that EU solutions elaborated on paper usually find an informal outlet in practice anyway - one example being the operation of joint investigation teams. ${ }^{11}$

\subsection{Feasible Ways to Organise Cooperation - Anything Goes?}

\subsubsection{Forms and Means of Police and Judicial Cooperation}

If one looks at forms and means of inter-State collaboration in the EU, there is cooperation of all sorts, which can be grouped together by common features such as: ${ }^{12}$

- traditional cooperation, such as requests for mutual assistance with regard to information or arrests; ${ }^{13}$

- cooperation relying on networking in a rather formal way, as in the European Judicial Network, or on an ad hoc basis such as the contact-point network set up to fight corruption; $;^{14}$

- 'co-active cooperation', such as the establishment of joint investigation teams ${ }^{15}$ or the organisation of joint controlled deliveries, ${ }^{16}$ even on an

11 See T. Schalken and M. Pronk, 'On Joint Investigation Teams', European Journal of Crime, Criminal Law and Criminal Justice (2002), p. 70 .

12 See J. Hecker, 'Europäisches Verwaltungskooperationsrecht am Beispiel der grenzüberschreitenden polizeilichen Zusammenarbeit', EuR (2001), p. 826; J. Pierini and G. Pasqua, 'Police Cooperation in the European Union. An Overview', in M. Bassiouni, V. Militello and H. Satzger (eds), op. cit., p. 407.

13 E.g. Convention Relating to Extradition between the Member States of the EU of 27.9.1995, Official Journal, C 313, 23.10.1996, p. 11; Convention on Simplified Extradition Procedure between the Member States of the EU of 10.3.1995, Official Journal, C 78, 30.3.1995, p. 2; Convention on Mutual Assistance in Criminal Matters between the Member States of the EU of 29.5.2000, Official Journal, C 197, 12.7.2000, p. 1 (EU Convention on MACM of 2000) and Protocol of 16.10.2001, Official Journal, C 326, 21.11.2001, p. 1.

14 Council Decision of 24 October 2008 on a Contact-point Network against Corruption, Official Journal, L 301, 12.11.2008, pp. 38-39.

15 See J. Pierini and G. Pasqua, op. cit., p. 407 with further references.

16 Regulations providing for the establishment of joint investigation teams: Art. 13 EU Convention on MACM of 2000; Council Framework Decision of 13.6.2002 on Joint Investigation Teams, Official Journal, L 162, 20.6.2002, p. 1; Council recommendation of 8.5.2003 on a Model Agreement for Setting up a Joint Investigation Team (ITT), Official Journal, C 121, 23.5.2003, p. 1; Regulations providing for joint controlled deliveries: Art. 12 EU Convention on MACM of 2000; Art. 73 Schengen Implementing Convention of 1990. 
ad hoc basis in crisis situations, ${ }^{17}$

- transborder cooperation, such as cross-border hot pursuit or surveillance; ${ }^{18}$ or cross-border data sharing, as outlined in the Council Decision of 23 June 2008, due to the increase in cross-border cooperation, particularly in the combat against terrorism and cross-border crime; ${ }^{19}$

- the establishment of shared institutions, such as Europol, ${ }^{20}$ or the establishment of shared databases, e.g. the Schengen Information System (SIS); ${ }^{21}$ and, last but not least,

- collaboration based on the principle of mutual recognition, ${ }^{22}$ which exists most prominently, at the moment, in the form of the European Arrest Warrant, ${ }^{23}$ but has brought with it various new initiatives for reshaping cooperation within the EU. ${ }^{24}$

17 Council Decision of 23 June 2008 on the improvement of cooperation between the special intervention units of the Member States of the EU in crisis situations, Official Journal, L 210, 6.8.2008, p. 73.

18 Arts 40 and 41 Schengen Implementing Convention of 1990; M. Daman, op. cit., p. 179.

19 Official Journal, L 210, 6.8.2008, p. 1.

20 Council Act of 26 July 1995 drawing up the Convention based on Art. K.3 of the Treaty on European Union, on the establishment of a European Police Office (Europol Convention) of 26 July 1995, Official Journal, C 316, 27.11.1995 as well as its protocols.

21 Art. 92 Schengen Implementing Convention of 1990.

22 See e.g. M. Hildebrandt, 'European Criminal Law and European Identity', Criminal Law and Philosophy (2007), p. 73 et seq.; G. de Kerchove and A. Weyembergh (eds), La reconnaissance mutuelle des decisions judicaires pénales dans l'Union européenne (Brussels 2001); S. Peers, 'Mutual Recognition and Criminal Law in the European Union. Has the Council Got it Wrong?', Common Market Law Review (2004), p. 5.

23 Council Framework Decision of 13.6.2002 on the European Arrest Warrant and the Surrender Procedures between Member States - Statements made by certain Member States on the adoption of the Framework Decision, Official Journal, L 190, 18.7.2002, p. 1; Europol will become a European agency in 2010.

24 See Council Framework Decision of 22.7.2003 on the Execution in the European Union of Orders Freezing Property or Evidence, Official Journal, L 196, 2.8.2003, p. 45; Council Framework Decision of 24.2.2005 on the Application of the Principle of Mutual Recognition to Financial Penalties, Official Journal, L 76, 22.3.2005, p. 16; Council Framework Decision of 6.10.2006 on the Application of the Principle of Mutual Recognition to Confiscation Orders, Official Journal, L 328, 24.11.2006, p. 59; Council Framework Decision of 18.12.2008 on the European Evidence Warrant for the Purpose of Obtaining Objects, Documents and Data for Use in Proceedings in Criminal Matters, Official Journal, L 350, 30.12.08, p. 72; Council Framework Decision of 27.11.2008 on the Application of the Principle of Mutual Recognition to Judgements and Probation Decisions with a View to the Supervision of Probation Measures and Alternative Sanctions, Official Journal, L $337,16.12 .08$, p. 102; Council Framework Decision of 27.11.2008 on the Application 


\subsubsection{Level of Cooperation and Institution-Building}

Looking at the degree of formal cooperation and institution-building, one can also distinguish various kinds of cooperation, as the following categories show:

- horizontal cooperation between the competent authorities of theEU Member States with little institution-building, e.g. the Schengen Framework, ${ }^{25}$ which is - except for the SIS ${ }^{26}$ - a rather 'grassroots' project of cross-border cooperation;

- vertical cooperation between the competent authorities of the EU Member States and EC agencies with independent institutions, such as OLAF, ${ }^{27}$ which coordinates the fight against fraud; ${ }^{28}$

- 'hybrid' vertical cooperation, e.g. the cooperation between the EU Member States and special EU agencies, such as Europol ${ }^{29}$ or Eurojust, ${ }^{30}$ which are run by the Member States, but are on the European level.

\subsubsection{Legal Framework and Rule-Making Authority}

Also, looking at the legal frameworks (and thus at the rule-making authorities) one can differentiate between: ${ }^{31}$

- international law in a traditional sense as adopted by a national legislator, especially the old conventions on mutual legal assistance or new police treaties; 32

- EC law as adopted by the EC institutions - e.g. all regulations concerning the fight against fraud affecting the financial interests of the EC, involving 'on-the-spot controls'; 33

of the Principle of Mutual Recognition to Judgements in Criminal Matters Imposing Custodial Sentences or Measures Involving Deprivation of Liberty for the Purpose of their Enforcement in the European Union, Official Journal, L 327, 5.12.08, p. 27.

25 See supra note 8.

26 See supra 3.1.1.

27 See supra 2.2.

28 For further information on the peculiarities of such cooperation see e.g. R. Traşcã, op. cit., p. 7.

29 See infra 3.2.

30 See infra 3.2.

31 For further information see e.g. E. Wagner, 'The Integration of Schengen into the Framework of the European Union', Legal Issues of European Integration (1998), p. 1.

32 See infra 3.2.

33 M. Anderson and J. Apap (eds), op. cit., p. 61; D. Flore, op. cit., p. 85. 
- 'EU law' as 'adopted by EU institutions' - such as the Council Decision that replaces the EU Convention and transforms Europol into a European Agency; ${ }^{34}$

- national laws as a foundation, including all laws on mutual assistance in criminal matters; and

- ad hoc regulations laid down by local competent authorities - e.g. for decisions concerning the establishment of joint investigation teams.

\subsection{Some Trends - Different Kinds of Cooperation}

Considering all the things going on within the field of Justice and Home Affairs, one would, at first sight, concede that 'anything goes':

- from refined mutual assistance in criminal matters, e.g. by means provided for by the EU Convention of 2000 which includes coactive and cross-border elements,

- through the establishment of mixed national/European frameworks and hybrid institutions, such as Europol and Eurojust,

- to mutual recognition, e.g. the European Arrest Warrant. ${ }^{35}$

When considering this spectrum, one misses a coherent European model for police and judicial cooperation that serves as an archetype and mould. Such a standard could not only help discuss and solve policy issues, but also serve as a starting point from which to develop rules and eventually a doctrine for cooperation within the EU. But even if a consistent pattern is missing, one can make out trends in European cross-border collaboration for fighting crime. Basically, one can distinguish two radical ends of a spectrum, namely traditional and vertical cooperation.

\subsubsection{Traditional Cooperation: No Institution-Building - International Law}

At one end of the spectrum, there is still traditional cooperation. But, as a rule, for the EU Member States traditional, cooperation (i.e. without modern 'coactive' or 'cross-border' elements) belongs in the past. ${ }^{36}$ The international law governing it consists mainly of conventions drafted in the forum of the Council of Europe. These conventions serve as so-called 'mother conventions' ${ }^{37}$ But the creation of

\section{See supra note 23.}

35 H. Nilsson, 'From Classical Judicial Cooperation to Mutual Recognition', International Review of Penal Law (2006), p. 57.

36 See e.g. C. Fijnaut, op. cit., p. 281.

37 See e.g. Arts 1 and 2 EU MACM. 
the EU 'area of freedom, security and justice' has outgrown their basic idea of mere mutual legal assistance from the day European judicial space came about ${ }^{38}$ and was given a programme and concrete agenda in Tampere. ${ }^{39}$

\subsubsection{Vertical Cooperation: EC Agencies - EC Law}

At the other end of the spectrum is vertical cooperation, which involves EC agencies, relying on EC law and following the principle of 'mutual recognition' without restriction, even in the area of law enforcement. ${ }^{40} \mathrm{~A}$ prominent example is the fight against fraud coordinated and implemented by OLAF on the grounds of regulations such as Regulation 2185/96 and Regulation 1073/99.

\subsubsection{Cooperation in Justice and Home Affairs}

Between traditional police and judicial cooperation between States and vertical cooperation within the EU, including collaboration between national authorities and EC agencies, is a grey area of cooperation. The so-called 'Third Pillar' of the EU opened up this wide range of nearly limitless possibilities.

Wherever we have a common framework, such as the Schengen cooperation, the choice of 'opting in' and 'opting out' of either of these commitments is possible for those who cannot (like Switzerland) or do not want to participate in the full range of possibilities.

\subsection{Evaluation of the Facts}

In looking at these facts - the 'results' - we see a lot. But what we see is a mess, chaos rather than order. Hence a preliminary conclusion can be drawn from the preceding discussion: if anything is possible, many things are tried out.

Even in academic ivory towers, however, we know, in the long run, that only some of the instruments developed for the EU framework are used successfully. And from experience we also know that if we do not get rid of useless instruments and finally agree on a coherent system, things get too complicated and the whole regime will not work. A legal system such as police and judicial cooperation

38 See e.g. C. Fijnaut, op. cit., p. 284; N. Dorn and S. White, "Beyond "Pillars" and "Passerelle” Debates. The European Union's Emerging Crime Prevention Space', Legal Issues of European Integration (1997), pp. 79-93; H. Nilsson, op. cit., pp. 53-58; H. Satzger and F. Zimmermann, op. cit., p. 360.

39 See M. Anderson and J. Apap (eds), op. cit., p. 11; W. Hetzer, 'National Criminal Prosecution and European Tendering of Evidence', European Journal of Crime, Criminal Law and Criminal Justice (2004), p. 166.

40 See R. Traşcã, op. cit., p. 19. 
needs method, structure and coherence; it needs an underlying concept of coordination and objective. ${ }^{41}$

For instance, one cannot have mutual assistance based on the traditional Conventions of 1957 and 1959 while establishing a European Public Prosecutor, because there will be cases with conflict between the relevant law, competences and jurisdictions.

Also, one cannot maintain traditional principles of mutual assistance (as, for example, the principle of speciality) while collecting evidence for another State while running common data systems giving access to the information on the principle of mutual recognition, because there will be the question of admissibility of such information in a criminal procedure. ${ }^{42}$

\section{Problems of Police and Judicial Cooperation}

These preliminary findings point to the problems of police and judicial cooperation faced today. Two problems appear to be most urgent.

\subsection{Introducing an Efficient, Coherent and Fair System of Police and Judicial Cooperation}

The first problem we have seen is the variety and mix of instruments in police and judicial cooperation, a situation that not only leads to fragmentation and inefficiency, but above all takes law enforcement interests into account rather than those of the defendant or the individual.

The challenge of the complex system - or rather systems - of cooperation ${ }^{43}$ in the EU is known and is also hinted at in the 'proposed solutions' of the High-Level Advisory Group on the Future of European Justice Policy, which points out that:

'the development of legal instruments to facilitate and enhance judicial cooperation in criminal matters has ... been in the centre of legislative work of the European Union over the last years'. ${ }^{44}$

41 M. Anderson and J. Apap (eds), op. cit., pp. 22, 24.

42 For further discussion of admissibility of evidence in European frameworks, see W. Hetzer, op. cit., pp. 166-183, 172.

43 The situation is partly a consequence of the flexibility approach in Justice and Home Affairs, see, e.g., A. Moravcsik and K. Nicolaïdis, 'Federal Ideals and Constitutional Realities in the Treaty of Amsterdam', Journal of Common Market Studies (1998), p. 31.

44 S. Bitter, 'Comment on Dagmara Kornobis-Romanowska', German Law Journal (2005), pp. 1641-1647. 
A sobering statement follows: "while significant progress was achieved much remains to be done. ${ }^{45}$ Thereafter it points succinctly to mutual recognition as a policy. But, in considering the present situation, the Group asserts that European cooperation will only be successful if the law enforcement authorities use all existing instruments. In practice, however, local law enforcement authorities are often asked to choose from among the various legal instruments in individual cases. This task leads to inefficacy, because the police and judiciary acting on the spot might refrain from participating in international teamwork.

Mutual recognition, in any case, is not the only solution proposed. Another strategy could be the reorganisation and redefinition of the European and national law enforcement institutions and their cooperation. ${ }^{46}$

The third difficulty mentioned, the protection of the defendant's rights in the framework of the fight against cross-border crime, has been a topic for much discussion, since the problem affects all forms of cooperation. ${ }^{47}$ It is also dealt with by the High-Level Advisory Group, which states in its June 2008 Report:

'Ensuring a high degree of protection for their rights in criminal investigations and proceedings throughout Europe, whether they are involved as victims or suspects or witnesses ... Securing citizens' rights is the foundation of our basic orders under the rule of law - both at the national and European level. As such, it is apparent in practically all life situations, but particularly in the area of state interference-for example in criminal investigation proceedings - and in the area of establishing judicial procedures to assert private-law claims, as well as to ensure protection of fundamental rights by the courts. ${ }^{.48}$

Although several initiatives were launched and worked on in order to establish procedural safeguards ${ }^{49}$ and minimum rights in criminal proceedings through-

45 High-Level Advisory Group, Report of June 2008, op. cit., p. III.3.1.

46 An example of such an initiative is the Communication from the Commission to the Council and the European Parliament on the role of Eurojust and the European Judicial Network in the fight against crime and terrorism in the EU, COM (2007) 644 final, which strengthens the position of Eurojust's powers as a European institution.

47 S. Gless, 'Mutual Recognition, Judicial Inquiries, Due Process and Fundamental Rights', in J. Vervaele (ed.), European Evidence Warrant. Transnational Judicial Inquiries in the EU (Antwerp 2005), p. 121; A. Smeulers, 'The Position on the Individual in International Criminal Cooperation', in J. Vervaele (ed.), op. cit., p. 79.

48 High-Level Advisory Group, Report of June 2008, op. cit., p. III.3.1.1.

49 C. Brants, 'Procedural Safeguards in the European Union. Too Little, Too Late?', in J. Vervaele (ed.), op. cit., p. 103; T. Rafaraci, op. cit., p. 363. 
out Europe, they all ultimately failed. The High-Level Advisory Group Report, nevertheless, is of the opinion that: ${ }^{50}$

'The consistent past decisions of the European Court of Justice have recognised an obligation on the part of the Community to respect fundamental rights as they are guaranteed in the European Convention of Human Rights and as general principles of Community law derived from the constitutional traditions common to the Member States. Based upon that formulation, which can be found in Article 6 (2) of the EU Treaty, the Court of Justice, in its judicial decisions, has developed these fundamental rights as general legal principles.' ${ }^{51}$

In enacting EU law, Member States also bear in mind the need to protect the fundamental rights of the individual - even if this might be just paying lip service. ${ }^{52}$ However, in the framework of the European Union little specific hard law has been enacted that efficiently protects individuals' rights affected by the fight against cross-border crime. Unfortunately the set-up of such 'human rights of European citizens' with regard to this particular area has so far failed..$^{53}$

\subsection{Establishing Accountability}

The second problem that I would like to address briefly (which is not dealt with by the High-Level Advisory Group) is the problem of accountability. Accountability of cross-border police and judicial cooperation has been a constant topic for discussion since the EU established such forms of collaboration. ${ }^{54}$

Let us consider two kinds of accountability:

- democratic accountability for legislation which shapes cooperation; and

- judicial accountability for certain acts within a cooperation.

50 Proposal for a Council Framework Decision on Certain Procedural Rights in Criminal Proceedings throughout the European Union [COM (2004) 328 final]; R. Lööf, 'Shooting from the Hip. Proposed Minimum Rights in Criminal Proceedings throughout the EU', European Law Journal (2006), p. 421.

51 High-Level Advisory Group, Report of June 2008, op. cit., p. III.3.1.2.

52 See e.g. Council Decision of 23.6.2008 on the Step-up of Cross-border cooperation, particularly in Combating Terrorism and Cross-border Crime, Official Journal, 210 , 6.8.2008, pp. 12-72.

53 M. Hildebrandt, op. cit., p. 75.

54 See M. Anderson and J. Apap (eds), op. cit., p. 13; M. den Boer, op. cit., pp. 275-289; D. Flore, op. cit., p. 85. 


\subsubsection{Democratic Accountability}

Legislation on police and judicial cooperation has so far been divided, roughly, ${ }^{55}$ between:

- national lawmakers (for horizontal police or judicial cooperation);

- European lawmakers (for vertical police or judicial cooperation; and

- a mixture of European and national legislators (for the 'hybridinstitutions' of the Third Pillar, such as Europol and Eurojust) - national and European agents, who have held each other responsible for the flaws in the system.

To comply with the rule of law, i.e. to create a legitimate legal system, each lawmaker must not only have the competence to create ${ }^{56}$ and implement rules, but must establish a system of democratic accountability. ${ }^{57}$ In an area where, from the beginning, the lawmaker - in this case the European Union - suffered from a weak legitimacy profile in the public's opinion, it is especially important to handle this requirement with care. Therefore the competent authorities should set up a strong regime of democratic accountability and guarantee transparency in the decision-making process.

Although the problem of democratic accountability at the European level, especially within the structure of the Third Pillar, is well known and has been widely criticised for a long time, previous treaties have tackled the problem with caution. ${ }^{58}$ The Lisbon Treaty is now trying to remove the democratic shortcomings, for example by asking for more involvement by the European parliament in the legislative process. In general, there is also a trend towards a more formal involvement by national parliaments, which could help to build the public's trust and ensure transparency and a lively exchange of views on European criminal justice policy at the national level.

However, as long as there are no clear-cut competences and explicit power divisions between national and European legislators and policy-makers, democratic accountability will remain a problem.

55 See also M. Anderson and J. Apap (eds), op. cit., p. 42.

56 A critical approach with regard to 'European criminal law' is presented by P.-A. Albrecht and S. Braum, 'Deficiencies in the Development of European Criminal Law', European Law Journal (1999), p. 293.

57 On the whole, national bodies have often not lived up to their commitments in Justice and Home Affairs and failed to implement relevant European law.

58 M. Anderson and J. Apap (eds), op. cit., p. 8; E. Spaventa, 'Opening Pandora's Box. Some Reflections on the Constitutional Effects of the Decision in Pupino', European Constitutional Law Review (2007), p. 6; A. Whelan, 'Fundamental Rights. Democracy and The Rule of Law in the Pillar', in G. Barrett (ed.), Justice Cooperation in the European Union (Dublin 1997), p. 207. 


\subsubsection{Judicial Accountability}

The lack of judicial accountability, i.e. the deficiency in jurisdictions for the accountability of courts and for judicial review, is not so much a problem for horizontal cooperation - where, as a general rule, national courts have jurisdiction - nor is it a problem for purely vertical cooperation - where the European Court of Justice exercises judicial control in general. The territorial State is liable for infringements of law by their own agents and by foreign agents unless the foreign officials act ultra vires or a contractual shift of responsibilities exists. It is rather that the hybrid institutions of the Third Pillar face problems, since they are neither part of the national nor fit into the EU judicial frameworks. ${ }^{59}$ According to Art. 35 TEU, the European Court of Justice has very limited jurisdiction with regard to this hybrid area. ${ }^{60}$

The High-Level Advisory Group realises that the protection of rights through the European Court of Justice is problematic. ${ }^{61}$ Although it points out, on the one hand, that the Court has helped to further the cause of judicial review in the area of fundamental rights in the existing framework so far, it does not, on the other hand, present any solutions to the problem of inadequate jurisdiction and control mechanisms. ${ }^{62}$

Although this deficiency of the EU Justice and Home Affairs framework has been widely criticised, ${ }^{63}$ the Member States only reluctantly put forward a solution for judicial review in the Lisbon Treaty ${ }^{64}$ Since the Lisbon Treaty changes the overall framework for the protection of individual's rights however, the chances of a new era with regard to these rights are quite promising. However, the June 2008 Report by the High-Level Advisory Group envisions: ${ }^{65}$

'With the Lisbon Treaty, the European Union's Charter of Fundamental Rights is to become binding law. With this, the fundamental rights proclaimed in the Charter will be binding not only for the bodies of the European Union and of Member States when implementing Community law; they will also be applied and interpreted by the Court of Justice.

59 See e.g. S. Gless, 'Rechtsvergleichender Querschnitt und rechtspolitische Bemerkungen', in S. Gless, R. Grote and G. Heine (eds), Justitielle Einbindung und Kontrolle von Europol (Freiburg im Breisgau 2001), vol. 1, p. 677; H. Satzger and F. Zimmermann, op. cit., p. 425.

60 E. Spaventa, op cit., p. 8.

61 High-Level Advisory Group, Report of June 2008, op. cit., p. III.1.1.1.

62 See High-Level Advisory Group, Report of June 2008, op. cit., p. III.1.1.2.

63 S. Gless, op. cit., p. 680; J. Monar, 'Justice and Home Affairs in the Treaty of Amsterdam. Reform and the Price of Fragmentation', European Law Review (1998), pp. 330-333.

64 See supra 4.2.2.

65 See High-Level Advisory Group, Report of June 2008, op. cit., p. III.1.1.2. 
This will contribute to an intensification of the European protection of fundamental rights. As such, with respect to the uniform area of freedom, security and justice, the Court of Justice might address issues involving fundamental rights both more often and more rapidly.'

In fact, the Lisbon Treaty would also provide the basis for further action in the field of minimum standards in the law of criminal procedure. The aim is not the harmonisation of national criminal procedural rights - at least not in an 'all the same' approach. Rather, harmonisation is understood as 'a process in which diverse elements are combined or adapted to each other so as to form a coherent whole while retaining their individuality' ${ }^{66}$ The High-Level Advisory Group's goal ${ }^{67}$ should be to provide all citizens of the European Union with a basic minimum set of rights should they come under scrutiny in a criminal investigation. Thus it suggests including at least the rights discussed for the proposal for a Framework Decision to strengthen the rights of the accused in criminal proceedings, ${ }^{68}$ and addressing additional measures. Such measures could, for example, include the introduction of minimum rules considering the presumption of innocence.

\section{Prospects for Reorganisation of Police and Judicial Cooperation}

We now look at the prospects for police and judicial cooperation after the Treaty of Lisbon has entered into force. Will this restructured and consolidated cooperation work for the future? What will future cooperation look like?

\subsection{Is Reorganisation Feasible under the Lisbon Treaty}

Reorganisation of police and judicial cooperation as such is not considered in the Lisbon Treaty.

\subsubsection{Judicial Cooperation}

The Lisbon Treaty addresses topics of judicial cooperation. Basically, in its Art. 82, it links judicial cooperation between EU Member States to the concept of mutual recognition. This assignment offers the chance for a solid rearrangement

66 M.Boodman, 'The Myth of Harmonization of Laws', American Journal of Comparative Law (1991), p. 700.

67 See High-Level Advisory Group, Report of June 2008, op. cit., p. III.1.1.3.

68 E.g. right to information with regard to procedural rights; right to defence counsel; right to an interpreter and to a translation of the relevant procedural documents. 
of such cooperation. In the future, the collaboration of judicial authorities would, in contrast to police cooperation, thus follow one model only: the judicial authorities of the Member States would accredit judicial decisions taken by their colleagues in other Member States in a lean procedure which builds on cross-border trust among the judiciary.

All the adopted measures for judicial cooperation based on the concept of mutual recognition are drafted in a similar way, with small variations due to the nature of the various aspects (arrest, seizure, financial penalties, freezing property, probation decisions, etc.) ${ }^{69}$

However, the Lisbon Treaty approach is rather cautious when it comes to various delicate issues. For example, it does not tackle the challenge of judicial review or of implementing compulsory minimum standards which ensure a fair trial and an effective evaluation system to monitor it.

The Lisbon Treaty brings about a more radical change in terms of possible reform of the cooperation between EU Member States' authorities and a potential European prosecution agency: Art. 86 Lisbon Treaty not only commits such judicial cooperation to the principle of mutual recognition, but, furthermore, opens up the prospect with regard to the establishment of a central European law enforcement agency, i.e. a European Public Prosecutor. In doing so, the Treaty takes into consideration many years of discussion, primarily triggered by the 'Corpus Juris' study ${ }^{70}$ related to the combating fraud affecting the Community budget.

However, the Lisbon Treaty again addresses the topic in a cautious way: The establishment of a European Public Prosecutor is - in the worst-case scenario of Art. 86 Lisbon Treaty - subject to enhanced cooperation, and tricky questions are as yet unanswered. The Lisbon Treaty does not, for example, provide an indication as to how this institution should be connected to national law enforcement or European cooperation. Neither does it determine a clear-cut division of tasks or competences for such a European Public Prosecutor. If, in the future, the Member States - or even just some of them (since the European Prosecutor is open to enhanced cooperation) - were to really designate a European Public Prosecutor according to Art. 86 Lisbon Treaty, judicial cooperation would have to be reorganised accordingly.

\subsubsection{Police Cooperation}

As already indicated the Lisbon Treaty sketches its vision of police cooperation only very roughly in Arts 87-89 - though without offering much further guidance.

69 For information on specific measures, see note 24.

70 M. Delmas-Marty and J. Vervaele (eds), The Implementation of the Corpus Juris in the Member States (Antwerp 2000), 4 vol. 


\subsubsection{Conclusion}

Reorganisation of police cooperation is thus not possible under the Lisbon Treaty. Also, reorganisation of judicial cooperation would have to follow the principle of mutual recognition.

\subsection{Solving the Problem of Accountability}

Does the Lisbon Treaty solve the second problem mentioned above, the problem of accountability?

\subsubsection{Democratic Accountability}

The Lisbon Treaty introduces a common 'ordinary' legislative procedure as a general rule, which applies to the area of cross-border law enforcement and cooperation in criminal matters.

However, there are some (important) deviations from the general rule in law-adopting requirements that cannot be explored in detail here. But it is important to note that:

(a) as a last resort, Member States can still claim 'fundamental aspects of their criminal justice systems'; and

(b) enhanced cooperation is an option for those who want to move on by leaving behind the reluctant; this creates different European legal frameworks.

For the sake of transparency and accountability of judicial and police cooperation it would be preferable to introduce this 'ordinary' legislative procedure for all areas. However, one has to accept that in the Member States all operational fields that work according to the unanimity rule are highly sensitive with regard to what could be described as 'national identity'. They fear a loss of competences that are crucial to their essential functions.

\subsubsection{Judicial Accountability}

Surprisingly, there is no specific reference in Title IV of the Lisbon Treaty to the jurisdiction of the Court of Justice over Justice and Home Affairs matters as such. Thus regular jurisdiction - according to Art. 256 Lisbon Treaty - must be applied. However, Art. 276 reads as follows:

'In exercising its powers regarding the provisions of Chapters 4 and 5 of Title V of Part Three relating to the area of freedom, security and justice, the Court of Justice of the European Union shall have no jurisdiction to review the validity or proportionality of operations carried out by the police or other law-enforcement services of a Member State or the exercise of the responsibilities incumbent upon Member States with 
regard to the maintenance of law and order and the safeguarding of internal security.'

It is not clear whether this modification is meant to be a broad curtailment, and thus is true also for the operations of judicial cooperation. At this moment nobody, therefore, knows whether this limitation will come to hold back judicial review. Furthermore, it is not clear yet, what the options of countries like the UK, Ireland and Denmark are. In order to avoid the Court's jurisdiction over a particular act, these countries simply want to opt out of judicial review in certain ways.

However, as mentioned above, the Lisbon Treaty also provides a basis for action in the field of criminal procedure. Furthermore, the Lisbon Treaty will strengthen the relationship with the European Charter of Fundamental Rights. Thus the European Court of Justice may also decide on the application and interpretation of the European Charter of Fundamental Rights with regard to police and judicial cooperation. Since this is possible within the scope of preliminary decision proceedings, a new era of judicial review could begin.

\section{Summary}

After this analysis of the facts and problems of police and judicial cooperation, the concluding question must be: what makes police or judicial cooperation work at all? Or conversely: when and why does it not work?

\subsection{The Classic Answer}

In traditional settings the question was: why do sovereign states assist each other in law enforcement? Why do they make other people's problems their own. The classic answer was: 'Do ut des ...', i.e. 'tit for tat ...'. This principle is easy to understand and is still at work outside the European Union's area of freedom, justice and security, and sometimes even inside it as well-reciprocity is always a requirement for mutual legal assistance in criminal matters.

\subsection{Principle of Solidarity}

Regarding police and judicial cooperation between EU Member States, several legal acts and institutions evoke a new spirit, or rather introduce a new legal doctrine to promote cross-border teamwork and replace the old thinking of "collaboration among and along the lines of sovereign states' ${ }^{71}$ This new approach builds on the principle of solidarity.

71 J. Vogel, 'The European Integrated Criminal Justice System and its Constitutional Framework', Maastricht Journal of European and Comparative Law (2005), p. 131. 


\subsubsection{Pupino Reasoning-Principle of Solidarity}

Prominent in such new reasoning is the famous Pupino decision. It-controversially - extended supranational principles, such as the concepts of effectiveness and loyalty based on Art. 10 TEC, to the classic Third Pillar domain. The details are disputed, but looking at the core of the matter, the Court's judgement mainly emphasises the importance of the loyalty principle within the European Union as a whole.

Although it was not a case directly connected with police or judicial cooperation, this judgement by theECJ also acknowledges a principle of solidarity, which includes the duty to cooperate loyally. ${ }^{72}$ The Court basically held that it would be very difficult for the Union to carry out its duties if the principle of loyal cooperation were not also binding in the Third Pillar. The principle of loyalty is enshrined in Art. $10 \mathrm{TEC}$ for EC law purposes, and requires that Member States take all measures necessary to ensure the fulfilment of their obligations under European law. The Court deduces that the principle of loyalty also applies to cross-border collaboration in Justice and Home Affairs and thus creates the principle of loyal cooperation. With the Pupino judgement, the Court of Justice has built a bridge, extending First Pillar principles to the Third Pillar. ${ }^{73}$

It is still, however, to be determined in detail (perhaps during discussions in workshops) whether and if so how this setting of EC law can be transferred to Justice and Home Affairs and its cooperation in various areas of law enforcement. The problems are apparent in all forms of cooperation, most clearly in connection with the European Arrest Warrant (EAW) and its abolition of dual criminality - and when it eventually comes to the approximation of laws. ${ }^{74}$

In practice - this much we also know in the ivory towers of Europe-mutual recognition (in all fields) only works where mutual trust exists. And for one reason or another, there appears to be less mutual trust in criminal matters than in civil proceedings.

\subsubsection{Solidarity - in the Face of a Policy of Mutual Recognition}

Some time has passed since the Pupino decision. The European institutions have not elaborated a specific principle of solidarity as a model for European police and judicial cooperation. A discussion about the implications of a duty

72 S. Bitter, op. cit.; E. Spaventa, op. cit., p. 22.

73 E. Herlin-Karnell, 'In the Wake of Pupino. Advocaten voor der Wereld and Dell'Orto', German Law Journal (2007), pp. 1147-1160.

74 For further information see A. Weyembergh, 'Approximation of Criminal Laws, the Constitutional Treaty and the Hague Programme', Common Market Law Review (2005), p. 1567; A. Klip, Criminal Law in the European Union (Inaugural lecture Maastricht University, 2004), p. 61. 
to cooperate loyally and about the obligations resulting from a principle of solidarity would have been helpful for defining ideas for future European police and judicial cooperation. It is more and more apparent that solidarity regarding cooperation in cross-border law enforcement is intrinsically tied to other issues concerned with the formation of a genuine European Union, namely building mutual trust. ${ }^{75}$ This is all the more true, since, as of late, cooperation within the $\mathrm{EU}$ in the domain of law enforcement has developed further towards a policy of mutual recognition.

The dedication to this particular instrument, its philosophy as well as its implications are clearly spelled out by Advocate General Ruiz-Jarabo Colomer in Advocaten voor de Wereld:

'the situation is no longer one where sovereign States cooperate in individual cases; instead it is one where Member States of the European Union are required to assist one another when offences which it is in the common interest to prosecute have been perpetrated' (C-303/05, No. 46).

Were this statement true, judicial cooperation at least would have outgrown a situation where 'anything goes, but nothing works'. Member States would be bound by an instruction or rather a doctrine which would oblige them to (re-) organise police and judicial cooperation in a way that advances and fosters legitimate common interests to prosecute in cross-border criminal cases. Such a duty would include a true commitment to adopt and implement a coherent policy for a European criminal justice system, spelled out in a pattern for police and judicial cooperation, which can in practice balance law enforcement interests and guarantee fair trials, while at the same time build trust through transparency and accountability. Given such ideals, Member States still have some way to go until the spirit of Pupino and Advocaten voor de Wereld prevails in the work of police and judicial cooperation.

The High-Level Advisory Group points to the problem stating:

'In the meantime, it has become clear that the mere application of the principle of mutual recognition of judicial decisions or those of investigative authorities is not sufficient to create a true area of freedom, security and justice. ${ }^{.76}$

In fact, it needs mutual trust - and veritable solidarity. In their analysis of Sovereignty and Solidarity: US and EU, being part of a study on Governing Work and Welfare in a New Economy, Josua Cohen and Charles F. Sabel illustrate that

75 M. Anderson and J. Apap (eds), op. cit. note 2, p. 17.

76 High-Level Advisory Group, Report of June 2008, op. cit., p. III.1.1.1. 
sovereignty - as legitimate political authorship - always rests on solidarity. ${ }^{77}$ In their view, solidarity is neither solely a sentiment of identity, nor simply complementarity rooted in the division of labour:

'Rather it is both moral and practical. Moral, in that individuals recognize one another as moral agents entitled to be treated as equals; practical, in that they are bound to each other by the recognition that each is better able to learn what he or she needs to master problems through collaboration with the others whose experiences, orientations and even most general goals differ from his or her own - a recognition that both expresses and reinforces a sense of human commonality that extends beyond existing solidarities. Such practical attachment is fostered by a pervasively uncertain world, where even the strongest have reason to favor a division of investigative labor to incurring the risks of choosing and executing a solution alone. In such a world the practical benefits that flow from constant testing and reexamination of assumptions and practices that defines a public provides a powerful motive to participate in collaborative problem solving on equal terms. ${ }^{78}$

If such solidarity were to animate police and judicial cooperation in the European Union, it might eventually enable the Union to establish sovereignty in crossborder law enforcement.

\section{Bibliography}

Albrecht, P.-A. and S. Braum, 'Deficiencies in the Development of European Criminal Law', European Law Journal (1999), pp. 293-310.

Alegre; S. and M. Leaf, 'Mutual Recognition in European Judicial Cooperation. A Step Too Far Too Soon?', European Law Journal (2004), pp. 200-217.

Anderson, M. and J. Apap (eds), Striking a Balance between Freedom, Security and Justice in an Enlarged European Union (Brussels 2002).

Barrett, G. (ed.), Justice Cooperation in the European Union (Dublin 1997).

Bassiouni, C., V. Militello and H. Satzger (eds), European Cooperation in Penal Matters. Issues and Perspectives (Padova 2008).

Bitter, S., 'Comment on Dagmara Kornobis-Romanowska', German Law Journal (2005), pp. 1641-1647.

Boer, den, M., 'Towards an Accountability Regime for an Emerging European Policing Governance', Policing and Society (2002), pp. 275-289.

77 J. Cohen and C. Sabel, Governing Work and Welfare in a New Economy (New York 2003), pp. 691-750.

78 J. Cohen and C. Sabel, op. cit., pp. 721-722. 
Brammertz, S., 'Eurojust. Parquet européen de la première génération', in G. de Kerchove and A. Weyembergh (eds), Vers un espace judiciaire pénal européen (Brussels 2000), pp. 105-118.

Brants, C., 'Procedural Safeguards in the European Union. Too Little, Too Late?', in J. Vervaele (ed.), European Evidence Warrant (Antwerp 2005), pp. 103-119.

Bruggeman, W., 'Europol et Interpol', in G. de Kerchove and A. Weyembergh (eds), Vers un espace judiciaire pénal européen (Brussels 2000), pp. 97-100

Cohen, J. and C. Sabel, Governing Work and Welfare in a New Economy. European and American Experiments (New York 2003).

Daman, M., 'Cross-Border Hot Pursuit in the EU', European Journal of Crime, Criminal Law and Criminal Justice (2008), pp. 171-207.

Dorn, N. and S. White, "Beyond "Pillars" and "Passerelle" Debates. The European Union's Emerging Crime Prevention Space', Legal Issues of European Integration (1997), pp. 79-93.

Fijnaut, C., 'Transnational Organized Crime and Institutional Reform in the European Union. The Case of Judicial Cooperation', in P. Williams and D. Vlassis (eds), Combating Transnational Crime. Concepts, Activities and Responses (London 2001), pp. 276-302.

Fijnaut, C., J. Wouters and F. Naert (eds), Legal Instruments in the Fight Against International Terrorism. A Transatlantic Dialogue (Leiden 2004).

Flore, D., 'Les acteurs d'un système de justice pénale européen', in G. de Kerchove and A. Weyembergh (eds), Vers une espace judiciaire pénal européen (Brussels 2000).

Gless, S., 'Mutual Recognition, Judicial Inquiries, Due Process and Fundamental Rights', in J. Vervaele (ed.), European Evidence Warrant (Antwerp 2005), pp. 121-129.

Gless, S., 'Introduction vor Hauptteil III', in W. Schomburg, O. Lagodny, S. Gless, T. Hackner, Internationale Rechtshilfe in Strafsachen (Munich 2006).

Guild, E., 'Crime and the EU's Constitutional Future in an Area of Freedom, Security and Justice', European Law Journal (2004), pp. 218-234.

Hecker, J., 'Europäisches Verwaltungskooperationsrecht am Beispiel der grenzüberschreitenden polizeilichen Zusammenarbeit', Europarecht (2001), pp. 826-845.

Herlin-Karnell, E., 'In the Wake of Pupino. Advocaten voor de Wereld and Dell'Orto', German Law Journal (2007), pp. 1147-1160.

Hetzer, W., 'National Criminal Prosecution and European Tendering of Evidence', European Journal of Crime, Criminal Law and Criminal Justice (2004), pp. 166-183.

Hildebrandt, M., 'Testing Expertise. Preuve and épreuve', New Criminal Law Review (2006), pp. 78-101.

Hildebrandt, M., 'European Criminal Law and European Identity', Criminal Law and Philosophy (2007), pp. 73-78.

Kerchove, de, G. and A. Weyembergh, Vers une espace judiciaire pénal européen (Brussels 2000). 
Kerchove, de, G. and A. Weyembergh, La reconnaissance mutuelle des décisions judiciaires pénales dans l'Union européenne (Brussels 2001).

Klip, A., Criminal Law of the European Union (Deventer 2005).

Lööf, R., 'Shooting from the Hip. Proposed Minimum Rights in Criminal Proceedings throughout the EU', European Law Journal (2006), pp. 421-430.

Monar, J., 'Justice and Home Affairs in the Treaty of Amsterdam. Reform at the Price of Fragmentation', European Law Review (1998), pp. 320-333.

Moravcsik, A. and K. Nicolaïdis, 'Federal Ideals and Constitutional Realities in the Treaty of Amsterdam', Journal of Common Market Studies (1998), pp. 13-38.

Nilsson, H., 'From Classical Judicial Cooperation to Mutual Recognition', International Review of Penal Law (2006), pp. 53-58.

Peers, S., 'Mutual Recognition and Criminal Law in the European Union. Has the Council Got it Wrong?', Common Market Law Review (2004), pp. 5-36.

Pierini, J. and G. Pasqua, 'Police Cooperation in the European Union. An Overview', in M. Bassiouni, V. Militello and H. Satzger (eds), European Cooperation in Penal Matters. Issues and Perspectives (Padova 2008), pp. 403-430.

Rafaraci, T., 'Procedural Safeguards and the Principle of Ne Bis In Idem in the European Union', in M. Bassiouni, V. Militello and H. Satzger (eds), European Cooperation in Penal Matters. Issues and Perspectives (Padova 2008), pp. 363-402.

Satzger, H. and F. Zimmermann, 'From Traditional Models of Judicial Assistance to the Principle of Mutual Recognition. New Developments of the Actual Paradigm of the European Cooperation in Penal Matters', in M. Bassiouni, V. Militello and H. Satzger (eds), European Cooperation in Penal Matters. Issues and Perspectives (Padova 2008), pp. 337-362.

Schalken, T. and M. Pronk, 'On Joint Investigation Teams', European Journal of Crime, Criminal Law and Criminal Justice (2002), pp. 70-82.

Schomburg, W., O. Lagodny, S. Gless and T. Hackner, Internationale Rechtshilfe in Strafsachen (Munich 2006).

Smeulers, A., 'The Position of the Individual in International Criminal Cooperation', in J. Vervaele (ed.), European Evidence Warrant (Antwerp/Oxford 2005), pp. 79-102.

Spaventa, E., 'Opening Pandora's Box. Some Reflections on the Constitutional Effects of the Decision in Pupino', European Constitutional Law Review (2007), pp. 5-24.

Traşcã R., 'La place de l'Office Européen de Lutte Antifraude dans la répression de la fraude au budget communautaire', Cahiers de droit européen (2008), pp. 7-82.

Vervaele, J., European Evidence Warrant. Transnational Judicial Inquiries in the EU (Antwerp 2005).

Vogel, J., 'The European Integrated Criminal Justice System and its Constitutional Framework', Maastricht Journal of European and Comparative Law (2005), pp. 125-147.

Wagner, E., 'The Integration of Schengen into the Framework of the European Union', Legal Issues of European Integration (1998), pp. 1-51. 
Whelan, A., 'Fundamental Rights. Democracy and The Rule of Law in the Third Pillar, Justice Cooperation in the European Union', in G. Barrelt (ed.), Justice Cooperation in the European Union (Dublin 1997), pp. 205-221.

Weyembergh, A., 'Approximation of Criminal Laws, the Constitutional Treaty and the Hague Programme', Common Market Law Review (2005), pp. 1567-1597. 